\title{
Genetic trends for milk, fat and protein in the Zimbabwean Holstein-Friesian population from 1973 to 1994
}

\begin{abstract}
Summary
Genetic trends based on 30395 records with parities 1 to 8 were estimated using average information restricted maximum likelihood algorithm (AIREML), which had overall mean, herd, month of calving, year of birth, parity and linear and quadratic effects of days in milk. Due to changes in the Zimbabwean milk recording system data set was split into records of cows born from 1973 to 1989 and the other from 1987 to 1994. The first data set was further split into even numbered herds (EVNH73) and odd numbered herds (ODNH73), due to computational limitations. The highest milk production was from May to August. Peak milk production was observed in parity 4. The heritabilities for FCM $(0.22$ to 0.26$)$, fat percent $(0.24$ to 0.28$)$ and protein percent $(0.21)$ were comparable to literature values. The annual genetic trends of FCM ranged from $8.36 \mathrm{~kg}$ to $13.2 \mathrm{~kg}$, fat per cent ranged from $0.0 \%$ to $-0.008 \%$ and protein per cent was $-0.003 \%$ in the three data sets. Genetic trends for milk yield, fat and protein yield were also positive but overally lower than in most other countries. The positive genetic trends obtained for milk, fat and protein yields imply that some progress has been made in increasing the milk production despite the relatively small population and significant restrictions. There is need to develop a selection index to improve milk yield and milk composition.
\end{abstract}

Key Words: Zimbabwe, Holstein-Friesian, FCM, Fal \%, Protein \%, genetic trends

\section{Zusammenfassung}

Titel der Arbeit: Genetischer Trend für Milch, Fett und Eiweiss in der Holstein-Friesian Population von Zimbabwe von 1973 bis 1994

Basierend auf 30395 Datensătzen mit Laktationen von eins bis acht wurden genetische Trends mit ATREML (averagc information restricted likelihood algorithm) geschatzt, wobei Herde, Kalbemonat, Geburtsjahr, Lakatation und lineare und quadratische Effekte fur Laktationstage berilcksichtigt wurden. Der Datensatz wurde aufgrund von Umstellungen im Milchleistungskontrollsystem geteilt in Kühe mit Geburtsjahr 1973 bis 1989 und in Kühe mit Geburtsjahr 1987 bis 1994. Da die Rechenkapazität nur begrenzt zur Verfugung stand, musste der erste Datensatz nach Herden mit geraden und in Herden mit ungeraden Nummern weiter geteilt werden. Die höchste Milchleistung wurde von Mai bis August festgestellt. In der vierten Laktation wurde die höchste Milchleistung erbracht. Die Heritabilitaten wurden für Fett-korrigierte Milchleistung (FCM) $(0,22$ bis 0,26$)$, Fettprozent $(0,24$ bis 0,28$)$ und Eiweissprozent $(0,21)$ geschatzt und sind damit mit Literaturwerten vergleichbar. Der jährliche Trend für FCM reichte von $8,36 \mathrm{~kg}$ bis $13,2 \mathrm{~kg}$, fur Fettprozent von 0.0 bis $-0.008 \%$ in den drei Datensătzen. Für Eiweissprozent wurde $-0,003 \%$ als jährlicher Trend geschătzt. Die genetischen Trends für Milch-, Fett und Eiweissmenge waren durchweg positiv. Dies zeigt, dass trotz der kleinen Population und erheblicher Restriktionen genetische Fortschritte erzielt werden konnten, auch wenn die Zahlen für den jährlichen genetischen Trend deutlich unter Vergleichswerten aus anderen Ländern liegen. Die Entwicklung und Einführung eines Selektionsindex wird empfohlen.

Schlüsselwörter: Zimbabwe, Holstein-Friesian Rinder, FCM, Fett-\%, Eiweiss-\%, genetischer Trend

\section{Introduction}

The effectiveness of any animal-breeding programme is measured by the genetic progress obtained. Both genetic and environmental improvements offer opportunity to 
increase the production of dairy cattle. One way to evaluate breeding programmes is to estimate the genetic trends. By analyzing the genetic trends, the need to take corrective measures or improve or even change the criteria used for choosing the genetic material (semen or embryos) for import to Zimbabwe may be highlighted. It may also point to the need to alter the environment in order to improve the expression of traits. Genetic trends measure the changes in the population and are the ultimate indicators of sustainable progress since this gain is cumulative and permanent. The historical trend analysis provides information to assess the current breeding strategy and to adjust for future market needs.

The mixed model methodology (MMM) initially described by HENDERSON (1975) has recently been used to determine what proportion of the phenotypic value is in fact genetic, It has been favored because MMM has smaller sampling variance and it accounts for competition by adjusting for differences in herd-mates of the daughters of the sires being evaluated.

The animal model incorporates all known genetic relationships in the population and is in particular an effective method of separating genetic and environmental effects (WIGGANS et al., 1988). The animal model accounts for changes in genetic variance as a result of selection (SORENSEN and KENNEDY, 1984; KENNEDY et al., 1988), The MMM requires that the variance components (genetic parameters) are known. Restricted Maximum Likelihood (REML) estimates the unknown parameters from the data. One such REML programmes is AIREML, which has the large sample properties of Maximum Likelihood (ML) and accounts for the loss of the degrees of freedom in the simultaneous estimation of fixed effects. It is robust against selection and nonrandom mating (MUSANI and MAYER, 1997).

\section{Materials and Methods}

The data comprised of 30395 (after edits) unadjusted production records from the Zimbabwe Dairy Services Association (ZDSA) for the period of calving from 1980 to 1998. Two sub data sets were created. The separation was for one data set to be for calvings from 1980 to 1993 (giving years of birth from 1973 to 1989). The second data set had records of calving from 1994 to 1998 (years of birth from 1987 to 1994). This was based on the fact that up to 1993 the lactation length was defined to be 300 days. During the same period fat percent was measured by the Gerber method. This was changed with the introduction of the statement system in 1994. The lactation length is now 305-days and the Bentley 2000 machine is used to measure fat and protein percentages,

Restrictions were imposed on the two data sets in an attempt to remove incorrect data and outliers. Only records of cows in parities 1 to 8 were included for the period 1973 to 1989 , and only records of cows in parities 1 to 7 for the period 1987 to 1994 . This was due to fewer animals in parities greater than 7 in the second data set. The first data set had 19755 records of lactation length 300-days. Due to computer memory limitations this data set was further split into even numbered herds (EVNH73) and odd numbered herds (ODNH73). The even numbered herds had 10638 records in 45 herds and the odd numbered herds had 9117 records in 47 herds. All herds with less than 10 cows and sires with less than 50 daughters were deleted and therefore excluded in the 
analysis. This was done besides reducing the data to a manageable size, to include only the sires that had really had an influence by having a large number of daughters which in turn would reduce prediction error variance (PEV), thus enhance accuracy of the estimation of Breeding Values (EBVs) (MRODE, 1996). No separate edits were done on the EVNH73 and ODNH73 data sets. The third data set (ALL87) comprised of 10 440 production records with days in milk ranging from 145 to 480 days for the calving period from 1994 to 1998 and years of birth were from 1987 to 1994 . There were 48 herds and 72 sires in the third data set.

The trait fat-corrected-milk (FCM) at $3.5 \%$ was computed using the equation:

FCM 3,5\% $\%$ (milk yield * 0.4324) $+($ fat yield * 16.218) (MAKUZA and McDANIEL, 1997).

The traits analysed for the period 1973 to 1989 were milk yield, fat-corrected-milk (FCM), fat yield and fat percent. For the period 1987 to 1994, the traits analysed included the above plus protein yield and protein percent.

Initial analyses using the General Linear Model (GLM) procedures of the Statistical Analysis Systems (SAS, 1994) were done to determine the non-genetic factors which affect milk yield, fat yield, fat percent, protein yield, protein percent and 3,5\% fatcorrected-milk (FCM). This led to the identification of fixed factors, which were later included in the animal model analysis. The fixed model, which was used, had the effects of herd, year of birth, month of calving and parity for EVNH73 and ODNH73 data sets with cows born from 1973 to 1989. The model for the data set ALL87 had the fixed effects of herd, year of birth, month of calving, parity and the linear and quadratic effects of days in milk. Days in milk was fitted as a covariate. This was because in the latter data set, there was great variation in days in milk to justify their inclusion in the analysis. The fixed effects of previous calving interval, days dry, days open and age at calving were excluded. Days open are not recorded at ZDSA. Also it is highly correlated to the calving interval. Age at calving confounded with parity and these two are highly correlated. Days dry confounded with calving interval and parity. This confounding was evident from the initial General Linear Model analysis of SAS, were the degrees of freedom were not what they were expected if these were included. MAKUZA and McDANIEL (1996) reported that the fixed effects, which included calving interval, days open, days dry among others were not estimable from parity 3 onwards using the data set from ZDSA for the period from 1973 to 1987 . Interactions among these fixed effects would result in them being nonestimable.

The variance components, heritabilities and repeatabilities were estimated using the Average Information Restricted Maximum Likelihood (AIREML) computer algorithm of GILMOUR (1995). The standard errors of the heritabilities obtained from running the AIREML were very high as a result, the formula of HAZEL and TERRILL (1945) was used to approximate them. The AIREML was restarted (cold starts) for each run at least 3 times after convergence to ensure that global maximum had been reached. The starting values for first iterations for the traits were taken from literature (MAKUZA and McDANIEL, 1996).

Two repeatability models were fitted. Model 1 was for cows born from 1973 to 1989 (data sets EVNH73 and ODNH73) had fixed effects of herd, year of birth, month of calving and parity and random effects of animal and error. 
Model 2 was for cows born from 1987 to 1994 (data set ALL87) and had the fixed and random effects as model 1 plus the linear and quadratic regression coefficients of days in milk. Annual genetic values were calculated as the average of the predicted breeding values for animals born in that year. The genetic trends were computed as the linear regression of mean annual genetic values on the year of birth (LNNDBERG et al., 1999),

\section{Results and Discussion}

The heritabilities and repeatabilities of all traits in the three data sets are shown in the Table. They were comparable to those reported by MAKUZA and MCDANIEL (1996). The variance components were lower than those reported for temperate climate values.

The annual genetic trends of FCM and fat percent were $8.36 \mathrm{~kg}$ and $0.0 \%$ for the EVNH73 data set (Figures 1 and 2). Annual genetic trends for the ODNH73 data set were $13.2 \mathrm{~kg}$ for FCM and $-0.001 \%$ for fat percent (Figures 3 and 4 ). For the ALL87 the annual genetic gains were $10.23 \mathrm{~kg}$ for FCM, $-0.008 \%$ for fat percent and -0.003 $\%$ for protein percent (Figures 5 to 7 ). The genetic trends for milk yield, fat yield and protein yield were similar to that for FCM. As expected the trends for fat percent and protein percent declined as that of milk yield increased. The negative genetic correlation between milk composition and milk yield has been described elsewhere (SIMIANER et al,, 1991). The annual genetic gains were lower than those reported by MAKUZA and McDANIEL (1997). Their figures were $68 \mathrm{~kg}, 49 \mathrm{~kg}$ and $\mathrm{l} \%$ for milk yield, FCM and fat per cent respectively. BURNSIDE et al. (1992) using data of Italian Holsteins, also reported higher gains per year, which were comparable to those obtained by MAKUZA and MCDANIEL (1997). HALLOWELL et al. (1998) reported annual genetic gains of $19 \mathrm{~kg}$ in first lactation cows in the South African Ayrshire cows. Their findings were comparable to those obtained in this study. The gains obtained in this study were higher than those reported by MUSANI and MAYER (1997) in a Jersey berd in Kenya.

Table

The genetic parameters and their standard errors for the three data sets ( $n=$ number of herds) (Genetische Parameter und Standardfehler fur die drei Datensătze; $\mathrm{n}=$ Zahl der Herden)

\begin{tabular}{|c|c|c|c|c|}
\hline Data & Trait & Heritability & Permanent environment & Repeatability \\
\hline \multirow{4}{*}{$\begin{array}{l}\text { EVNH73 } \\
n=46\end{array}$} & Milk yield (kg) & $0.26(0.08)$ & $0.16(0.08)$ & $0.42(0.08)$ \\
\hline & FCM $(\mathrm{kg})$ & $0.23(0.07)$ & $0.12(0.07)$ & $0.35(0.07)$ \\
\hline & Fat $(\mathrm{kg})$ & $0.21(0.06)$ & $0.10(0.06)$ & $0.31(0.06)$ \\
\hline & Fat $(\%)$ & $0.24(0.07)$ & $0.13(0.07)$ & $0.37(0.07)$ \\
\hline \multirow{4}{*}{$\begin{array}{l}\text { ODNH73 } \\
\mathrm{n}=47\end{array}$} & Milk yield $(\mathrm{kg})$ & $0.26(0.08)$ & $0.16(0.08)$ & $0.42(0.08)$ \\
\hline & FCM (kg) & $0.23(0.06)$ & $0.13(0.06)$ & $0,36(0,06)$ \\
\hline & Fat yield $(\mathrm{kg})$ & $0.22(0.07)$ & $0.11(0.07)$ & $0.33(0.07)$ \\
\hline & Fat $(\%)$ & $0.28(0.09)$ & $0.19(0.09)$ & $0.47(0.09)$ \\
\hline \multirow{6}{*}{$\begin{array}{l}\text { ALL } 87 \\
n=49\end{array}$} & Milk yield (kg) & $0.23(0.05)$ & $0.12(0.05)$ & $0.35(0.05)$ \\
\hline & FCM (kg) & $0.2 \mathrm{t}(0.04)$ & $0.09(0.04)$ & $0.30(0.04)$ \\
\hline & Fat $(\mathrm{kg})$ & $0.21(0.04)$ & $0.09(0.04)$ & $0.30(0.04)$ \\
\hline & Protein (kg) & $0.21(0.04)$ & $0.10(0.04)$ & $0.31(0.04)$ \\
\hline & Fat $(\%)$ & $0.28(0.06)$ & $0.26(0.06)$ & $0.54(0.06)$ \\
\hline & Protein $(\%)$ & $0.20(0.04)$ & $0.17(0.04)$ & $0.37(0.04)$ \\
\hline
\end{tabular}




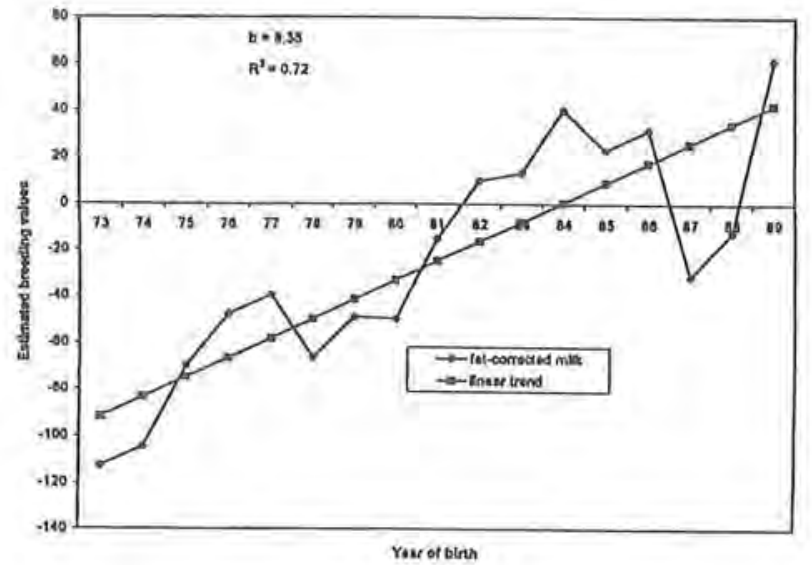

Fig. I: Genetic trend for fat-corrected-milk in even numbered herds from 1973 to 1989 (Genetischer Trend fur Fett-korrigierte Milchleistung fur gerade Herdennummern von 1973 bis 1989)

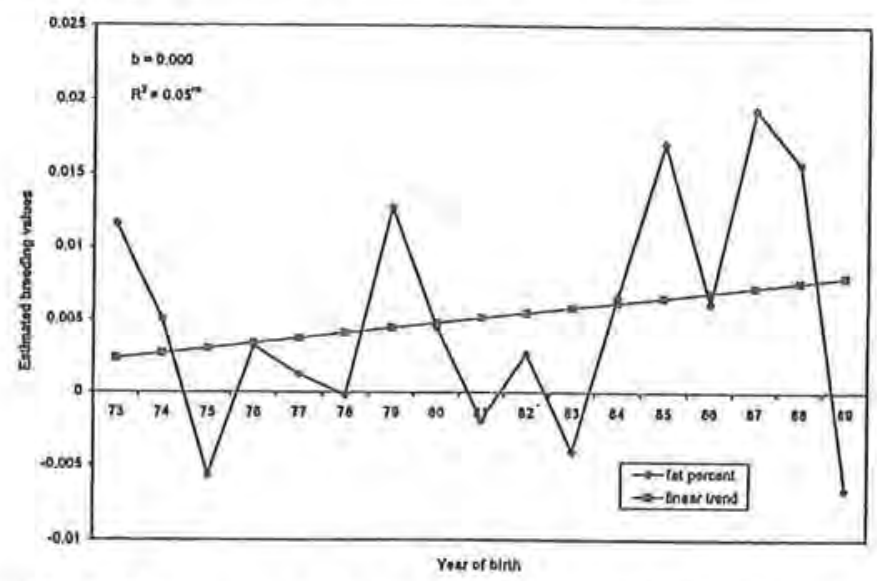

Fig. 2: Genetic trend for fat \% in even numbered herds from 1973 to 1989 (Genetischer Trend fur Fettprozent in geraden Herdennummern von 1973 bis 1989)

Several factors may have contributed to the differences in genetic trends compared to published data. One reason could be the differences in sample sizes. MAKUZA and McDANIEL (1997) used MTDFREML on a main frame computer, which accommodated a larger data set compared to the AIREML on a personal computer used in this study. Secondly the intensity of selection; In the past there were sanctions against Zimbabwe (then Rhodesia) until 1980, which restricted imports including semen or embryos into the country. The effective population size from which selection could be applied was therefore relatively small resulting in low selection intensity. Further severe droughts occuring in 1992/93 and 1995/96 resulted in huge losses of dairy animals. Thus the dairy farmers in Zimbabwe are in the process of restocking their herds and more animals of mediocre performance are retained. All these factors will contribute probably to the low average genetic trends. 


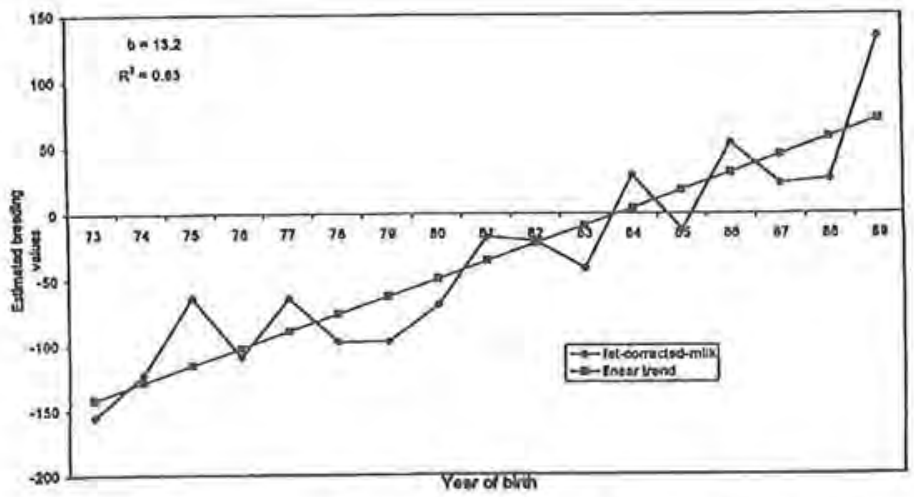

Fig. 3: Genetic trend of fat-corrected-milk in odd numbered herds from 1973 to 1989 (Genetischer Trend fur Fett-korrigierte Milchleistung in ungeraden Herden von 1973 bis 1989)

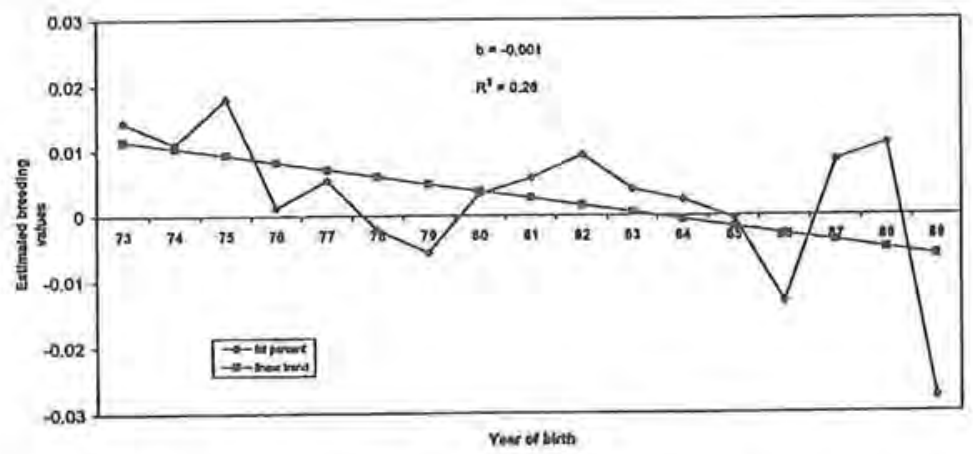

Fig. 4: Genetic trend of fat \% in odd numbered herds from 1973 to 1989 (Genetischer Trend fur Fettprozent in ungeraden Herdennummem von 1973 bis 1989)

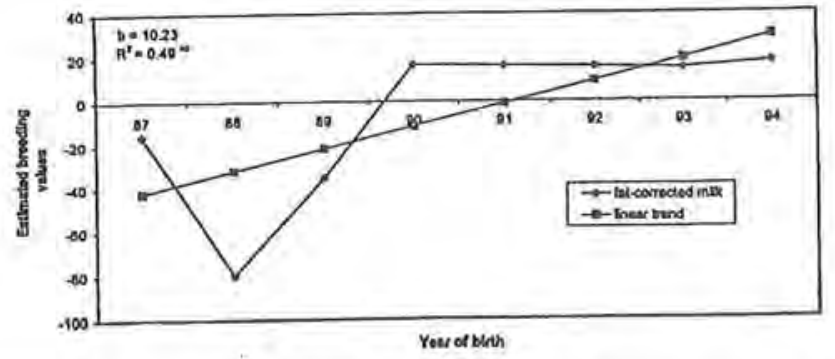

Fig. 5: Genetic trend for fat-corrected-milk in herds from 1987 to 1994 (Genetischer Trend fur Fett-korrigierte Milchleistung in Herden von 1987 bis 1994) 


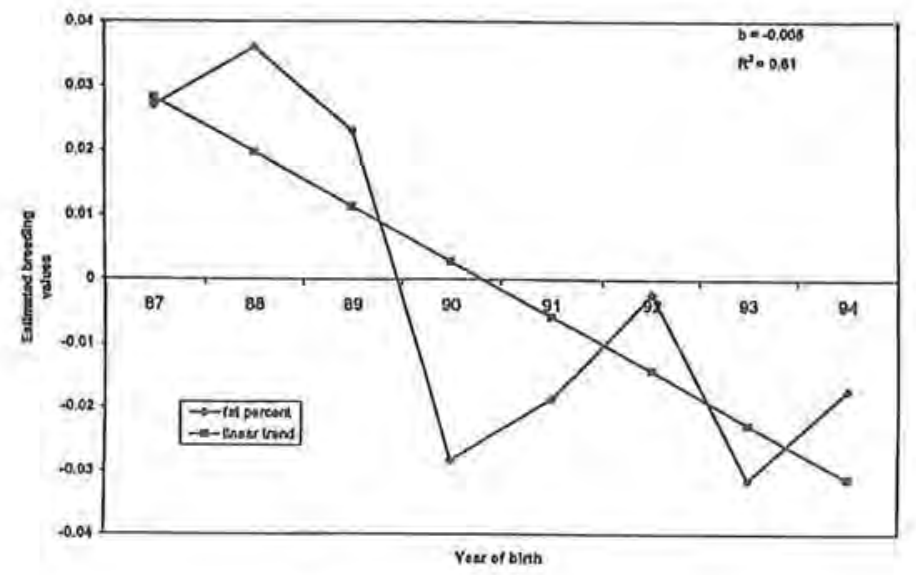

Fig, 6: Genetic trend for fat \% in herds from 1987 to 1994 (Genetischer Trend für Fettprozent in Herden von 1987 bis 1994

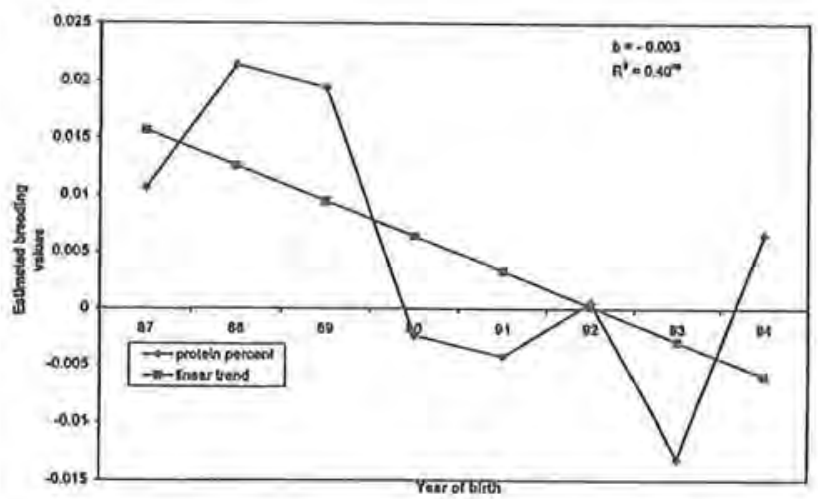

Fig. 7: Genetic trend for protein \% in herds from 1987 to 1997 (Genetischer Trend fur Eiweissprozent in Herden von 1987 bis 1997)

\section{Conclusion}

Herd, year of birth, month of calving, parity, linear and quadratic effects of days in milk and the quadratic effect of days in milk significantly affected milk yield, FCM, fat yield and protein yield. There was no variation in fat percent and protein percent with month of calving. May to August gave the highest yields in all the three data sets. Peak production occurred at parity four. Therefore farmers should consider keeping cows to parity 4 to 7. Milk traits in Zimbabwean Holstein cattle had heritabilities and repeatabilities that were comparable to those from elsewhere. The variance components were lower than earlier reports on the same population. There were positive genetic trends in cows born from 1973 to 1989 for milk yield, FCM and fat yield. However, the genetic trends for fat percent was negative. The cows born from 
1987 to 1994 (data set ALL87) also had positive genetic trends. The trends for fat percent and protein percent were negative.

There is need to develop adjustment factors for days in milk (lactation length). There were positive genetic trends for milk, fat and protein yield. However, the genetic trends for fat and protein percent were negative indicating an antagonistic relationship between milk yield and milk composition. Overall the observed genetic trends were lower compared to estimates from other countries or dairy cattle populations. Therefore it is important to regularly provide farmers and organisations with information on genetic trends to establish the effect of selection and determine future selection strategies.

\section{Acknowledgement}

The authors wish to sincerely thank the Deutsche Gesellschaft fur Technische Zusammenarbeit (GTZ) for funding this research, Zimbabwe Dairy Services Association for providing the data and the Animal Science Departments of the Universities of Zimbabwe and Malawi for providing all the necessary support.

\section{References}

BURNSIDE, E.B.; JANSEN, G.B.; CIVATI, G.; DADATI, E.:

Observed and theoretical genetic trends in large dairy population under intensive selection. J. Dairy Sci. 75 (1992), 2242-2253

GILMOUR, A.:

Average Information Restricted Maximum Likelihood Manual. Polycopy, (1995)

HALLOWELL, G. J.; VAN DER WESTHUIZEN, N., VAN WYK, J. B.:

Genetic and environmental trends for first lactation milk traits in the South African Ayrshire breed South African. J. Anim. Sci. 28 (1998), 38-45

HAZEL, L.N,; TERRILL, C.E.:

Heritability of weaning weight and staple length in range Rambouillet lambs. J. Anim. Sci. 4 (1945), 347-358

HENDERSON, C.R.:

Use of all relatives in intraherd prediction of breeding values and producing abilities. J. Dairy Sci. 58 (1975), 1910-1916

KENNEDY, B.W.; SCHAEFFER, L.R.; SORENSEN, D.A.:

Genetic properties of animal models. J. Dairy Sci. 71 (1988), Suppl. 2

LINDBERG, C.M.; SWANSON, G.J.T,; MRODE, R.A.:

Genetic trends in linear type traits in the United Kingdom dairy breeds. In: Proc. of the British Society of Anim. Sci. Abstracts: 80 (1999)

MAKUZA, S.M. MCDANIEL, B,T:

Effects of days dry, previous days open, and current days open on milk yields of cows in Zimbabwe and North Carolina. J. Dairy Sci. 79 (1996), 702-709

MAKUZA, S.M.; MCDANIEL, B.T:

Genetic and phenotypic trends Holstein herds in Zimbabwe. J. Zimb. Soc. Anim. Prod. 8 (1997), 111 114

MRODE, R.A.:

Linear models for the predicting the breeding values of animals. CAB International, 1996

MUSANI, S.K.; MAYER, M.:

Genetic and environmental trends in a large Jersey herd in Central Rift Valley Kenya. Trop. Anim. Health.Prod, 29 (1997), 108-116

SAS:

User's Guide; Statistics, Version 6.10 edition SAS Inst. , Inc., Cary N.C. 1994 
SIMIANER, H.; SOLBU, H.D.; SCHAEFFER, L.R.:

Estimated genctic correlations between disease and yield traits in dairy cattle. J. Dairy Sci. 74 (1991), 4358-4365

SORENSEN, D.A.; KENNEDY, W.B.:

Estimation of genetic variances from unselected and selected populations. J. Anim. Sci. 59 (1984), 1213-1223

WIGGANS, G.R;; MISZTAL, I.; AN VLECK, L.D.:

Implementation of an animal model for genetic evaluation of dairy cattle in the U.S.. J. Dairy Sci. 71 1988, (Suppl.2): 54

\author{
Received: 2000-02-09 \\ Accepted: $2000-11-03$ \\ Authors' addresses \\ KIZITO KUNAKA \\ Gwebi College of Agriculture \\ P. Bag $376 \mathrm{~B}$ \\ Harare \\ Zimbabwe \\ Tel.: +2634304515 Ext, 2014 or 2004 \\ Dr. STANLEY M. MAKUZA \\ University of Zimbabwe \\ Department of Animal Science \\ P.O. Box MP 167 \\ Mount Pleasant \\ Harare, Zimbabwe \\ Tel.; 2634303211 Ext. 1644 \\ Prof. Dr. CLEMENS B.A. WOLLNY \\ Dr. J. W. BANDA \\ University of Malawi \\ Bunda College of Agriculture \\ P. O. Box 219 \\ Lilongwe,Malawi \\ Tel. : 265781227 \\ Fax: +265 784394 \\ Fax: 265277364 \\ ClemensWollny@malawi.net and \\ ClemensWolinv(@)compuserve.com
}




\title{
Buchbesprechung
}

\author{
Ernahrung landwirtschaftlicher Nutztiere \\ HEINZ JEROCH, WINFRIED DROCHNER, ORTWIN SIMON
}

544 Seiten, 140 Abbildungen, 200 Tabellen, Verlag Eugen Ulmer, Stuttgart, 1999, (Reihe UTB fulr Wissenschaft), ISBN 3-8252-8180-9, DM 98,00; ठS 715,00; sFr 89,00

Mit dem vorliegenden Standardwerk haben die renommierten Herausgeber, einschließlich des Autorenkollektivs, ein Buch vorgelegt, welches sich von in jüngerer Zeit erschienenen Titeln dieses Fachgebietes besonders auszeichnet, In einer bisher nicht ublichen Form werden wissenschaflich auf dem neuesten Stand, ubersichtlich und fuir einen breiten Leserkreis verständlich, die Gesamtheit des Faches Tierernăhrung mit seinen Teilgebieten der Emăhrungsphysiologie, Futtermittel- und Futterungskunde, alle notwendigen Informationen abgedeckt. Das gelang nur, weil sich die Textdarstellung dieses großen Stoffumfanges auf das Wesentliche beschränkt und zahlreithe Abbildungen und Tabellen die Aussagen wirkungsvoll unterstatzen. Daruber hinaus zeichnet sich das Buch durch eine klare, verständliche Sprachkultur aus. In seiner Komplexität von den Grundlagen bis zur praktischen Fütterungsempfehlung macht sich dieses Buch für jeden, der sich mit der Futterung landwirtschaftlicher Nutztiere in der akademischen Ausbildung, der praktischen Tätigkeit, in der Beratung oder anderen tangierenden Fachbereichen beschätigt, unentbehrlich.

Der Inhalt gliedert sich in drei Hauptteile. Die Themenauswahl des ersten Teiles zur Ernăhrungsphysiologie vermittelt Grundlagenwissen, welches fur das Verständnis des Gesamtgebietes notwendig ist. In gut überschaubarer Gliederung, was übrigens für das ganze Buch gilt, werden die Komplexe „Biochemische Grundlagen" u.a. mit Informationen uber die Inhaltsstoffe, Analytik, das Vorkommen, Eigenschaften, Umsatz und physiologische Bedeutung der Hauptnăhrstoffe, Mineralstoffe und Vitamine beschrieben. Es folgen die Komplexe über die Futteraufinahme und ihre Regulation, die Verdauung und Resorption, Energiehaushalt sowic Verwertung des EiweiBes und Eiweißbewertung. Hervorzuheben sind in diesem und den weiteren Hauptteilen die sehr gute didaktische Aufbereitung des Sachinhaltes. Drucktechnische Texthervorhebungen von Hauptbegriffen erleichtem die Übersicht ebenso, wie die Textmarkierungen von Merksătzen oder Hauptaussagen. Der zweite Hauptteil ist der Futtermittelkunde gewidmet. Nach Darstellung wichtiger futtermittelrechtlicher Vorschriften folgen die Beschreibung der einzelnen Futtermittel geordnet nach botanischen Merkmalen, Herkunft und Erzeugung. Den Abschluss bildet ein umfangreiches Futtermitteltabellenwerk. Der dritte und umfangreichste Buchteil „Futterung" enthält für die Tierarten Schwein, Pferd, Rind, Schaf, Hulmergeflugel und Puten, die physiologischen Grundlagen und Aussagen zum leistungsbezogenen Energie-sowie Năhrstoffbedarf für die einzelnen Alters- und Nutzungsgruppen bis zu fütterungsbedingten Einflüssen auf das Endprodukt oder Gesundheitsstörungen. Hilfreich für den Nutzer des Buches sind die Orientierungen fur Rationskalkulationen, die Rationsbeispiele und die besonderen Hinweise, die als „Kommentare" ausgewiesen sind.

Der Inhalt des vorliegende Standardwerkes genlagt hohen Ansprilchen. Es ist in erster Linie Studierenden aller tangierenden Fachrichtungen sehr zu empfehlen. Durch seine Leserfreundlichkeit, den hohen, vielseitigen Informationswert und große Praxisrelevanz, ist es daruber hinaus vor allem Landwirten, Tierărzten, Mitarbeitern der Futterindustrie, Lehrenden, Beratungskräften und weiteren Nutzern als unentbehrliches Arbeitsmittel sehr zu empfehlen. 